Volumen 16 Número 3, Julio - Septiembre 2021, pp. 1-14, e622

THE ECONOMICS AND FINANCE EFFECTS OF THE COVID-19 PANDEMIC Editor: Dr. Ignacio Perrotini

DOI: https://doi.org/10.21919/remef.v16i3.622

\title{
Expansionary Policy in Pandemics, a Dynamic Model Examination
}

\author{
Leopoldo Gómez-Ramírez ${ }^{1}$ - Universidad del Norte, Colombia \\ Alexander Villarraga-Orjuela ${ }^{2}$ - Universidad del Norte, Colombia
}

The objective of this paper is to examine the issue of expansionary policies during the pandemic in Mexico. To do so, we use a dynamic model of the interaction between Covid-19 and economic output. We find that expansionary policies are desirable but that they alone cannot prevent the acceleration of the pandemic. We also model supplementary policies, especially public health policies, and find that in their presence expansionary economic policies can put the economy on track while simultaneously addressing the pandemic. Our analysis's implications are straightforward: countercyclical economic policies are desirable when there are other supplementary policies. A limitation of our analysis is that it is circumscribed to the Mexican context. The paper is a novel contribution to the burgeoning literature on Covid-19 in Mexico because it is the first which formally examines the issue of expansionary policies during the pandemic. We conclude that both expansionary policies and supplementary policies are needed to achieve a sustainable recovery.

JEL Classification: H12, H51, I18, H39, E69.

Keywords: Covid-19, expansionary policies, public health policies, Mexico.

\section{Política expansiva en pandemia, una investigación con un modelo dinámico.}

El objetivo de este artículo es examinar el problema de las políticas expansivas durante la pandemia en México. Para hacer eso, usamos un modelo dinámico de la interacción entre Covid-19 y la producción económica. Encontramos que las políticas expansivas son deseables pero que, solas, no pueden prevenir la aceleración de la pandemia. También modelamos políticas suplementarias, particularmente de salud pública, y encontramos que en su presencia las políticas económicas expansivas pueden poner a la economía en buen camino mientras que simultáneamente enfrentan a la pandemia. Las implicaciones de nuestro análisis son claras: políticas contracíclicas son deseables cuando existen otras políticas suplementarias. Una limitación de nuestro análisis es que está circunscrito al contexto de la economía mexicana. El artículo es una contribución original en la floreciente literatura sobre Covid-19 en México, porque es el primero que examina formalmente el problema de las políticas expansivas durante la pandemia. Nuestra conclusión es que tanto políticas expansivas como políticas suplementarias son necesarias para lograr una recuperación sostenible.

Clasificación JEL: H12, H51, I18, H39, E69.

Palabras clave: Covid-19, políticas expansivas, políticas de salud pública, México.

1 Email: leopoldog@uninorte.edu.co

${ }^{2}$ Corresponding author. Dirección: Kilometro 5 s/n vía Puerto Colombia, Colombia. C.P. 0800001142. Bloque D-26.

Teléfono: (+57) 53509509 extensión 4505. Email: avillarraga@uninorte.edu.co

* No source of funding for research development

** Leopoldo Gómez-Ramírez and Alexander Villarraga-Orjuela thank Anders Fremstad (Colorado State University) for his comments on the paper and for English language editing. The usual disclaimers apply. 


\section{Introduction}

The impact of the Covid-19 pandemic on the Mexican economy has been severe. Data from the Mexican National Institute of Statistics and Geography (INEGI) shows that, compared with 2019, 2nd quarter output, investment, and consumption contracted by $18.6 \%, 27.9 \%$, and $14.8 \%$, respectively. This constitutes the sharpest economic downturn for the Mexican economy in its modern history, larger more significant than the 1995 and 2008 crises. ${ }^{3}$ Some scholarly papers have already examined Covid-19's effects on poverty and employment, finding the first increased and the second decreased (Esquivel, 2020; Salas et al., 2020; Samaniego, 2020; Zuñiga, 2021). Therefore, it should not be surprising, that many economists and policymakers have called for expansionary "Keynesian" policies in order to achieve economic recovery. In this view, Mexico should promote expansionary monetary policy accompanied by increased government expenditures and/or cut taxes, or both. It has been ubiquitously expressed in opinion columns and by media commentators. There is already burgeoning scholarly literature making the case for Keynesian policies to address the crisis as well (Casar, 2020; Cárdenas, 2020; Panico, 2020; Moreno-Brid, 2020). ${ }^{4}$

Unfortunately, Covid-19 does not constitute a standard economic crisis that can be thoroughly addressed by expansionary monetary or fiscal policy. In the absence of additional policies, expansionary economic policy could also boost the contagion rate (if it could not, why did the government close the economy in the first place?). ${ }^{5}$ For this reason, there is a need for a deeper examination of expansionary policies in viral pandemics.

In this paper, we examine the issue of expansionary economic policies in the context of the pandemic. We carry out the investigation with our analysis of a dynamic model. Our findings can be summarized in two sentences. First, while expansionary policies can help the country avoid the worst-case scenario in which the pandemic grows and output shrinks, expansionary policies cannot avoid -and might contribute to- the spread of Covid-19. Second, supplementary policies, especially public health policies, make it possible to achieve the best-case scenario in which Covid-19 shrinks and output grows. Thus, when coupled with such supplementary policies, countercyclical policies can also help put society in the best-case scenario. The bottom-line message of our analysis is, therefore, that a package of expansionary policies is fully desirable if there are also other supplementary policies, especially public health policies.

There is a growing literature arguing Mexico's policy response to the pandemic provides an opportunity for addressing longstanding issues like poverty and inequality by building a social welfare state while simultaneously achieving a full economic recovery (Cordera, 2020, Moreno-Brid 2020, Suárez-Davila, 2020, Toporowski and Levy-Orlik, 2021). Without disregarding these valuable

\footnotetext{
${ }^{3}$ According to World Bank data, the economy contracted $-6.2 \%$ in 1995 , and it contracted $-5.3 \%$ in 2008 . Interestingly, as of October 2020, Dávila-Flores and Valdés-Ibarra (2020) estimated that the shutdown of "non-essential" economic activities reduced GDP, disposable income, and private consumption by 7\%, 6.5\%, and 6.4\%, respectively.

4Esquivel (2020) replies to the commentators regretting the absence of larger expansionary policies. Among other reasons, he argues that Mexico's government's response capacity could not have been as strong as the one of a developed economy. 5Sundaram (2020 p. 1062) makes a similar point when he says that "The essence of this crisis [of Covid-19] is that it cannot be solved simply with a fiscal stimulus."
} 
insights, this paper focuses on the more basic issue of countercyclical policies in the middle of the pandemic. 6

The rest of the paper is organized as follows. Section 2 presents stylized facts on Covid-19's impact on the Mexican economy. Section 3 presents the baseline model of the interaction between Covid-19 and economic output. Section 4 extends the model to allow for supplementary policies, especially public health policies. In the concluding comments section 5 , we summarize.

\section{The pandemics impact on the Mexican Economy. Stylized facts}

The toll of the pandemic on the Mexican economy has been substantial, as shown by the previous data on GDP, investment, and consumption, as well as the burgeoning empirical literature on Covid19's impact on the country (Esquivel, 2020; Salas et al. 2020; Samaniego, 2020; Zuñiga, 2021).

Figure 1 presents data on Mexico's quarterly real GDP growth rates (\%) from the fourth quarter of 2019 to the fourth quarter of 2020. These rates are in comparison with the same quarter of the previous year. Interestingly, it shows that before the pandemic output had already experienced some slowdown. Nevertheless, it shows that in the second quarter of 2020, Mexican output declined by $18.6 \%$, which is an extraordinary shock. It is, in fact, the sharpest economic downturn in the country's modern history, significantly greater than the crises occurring in 1995 and 2008 (see footnote 1). Figure 1 also shows that in the third and fourth quarter of 2020, the contractions were of $8.6 \%$ and $4.5 \%$, respectively, which are also quite large for a developing economy in serious need to achieve high and sustained growth. At the end of 2020, Mexico was still in a severe crisis. ${ }^{7}$

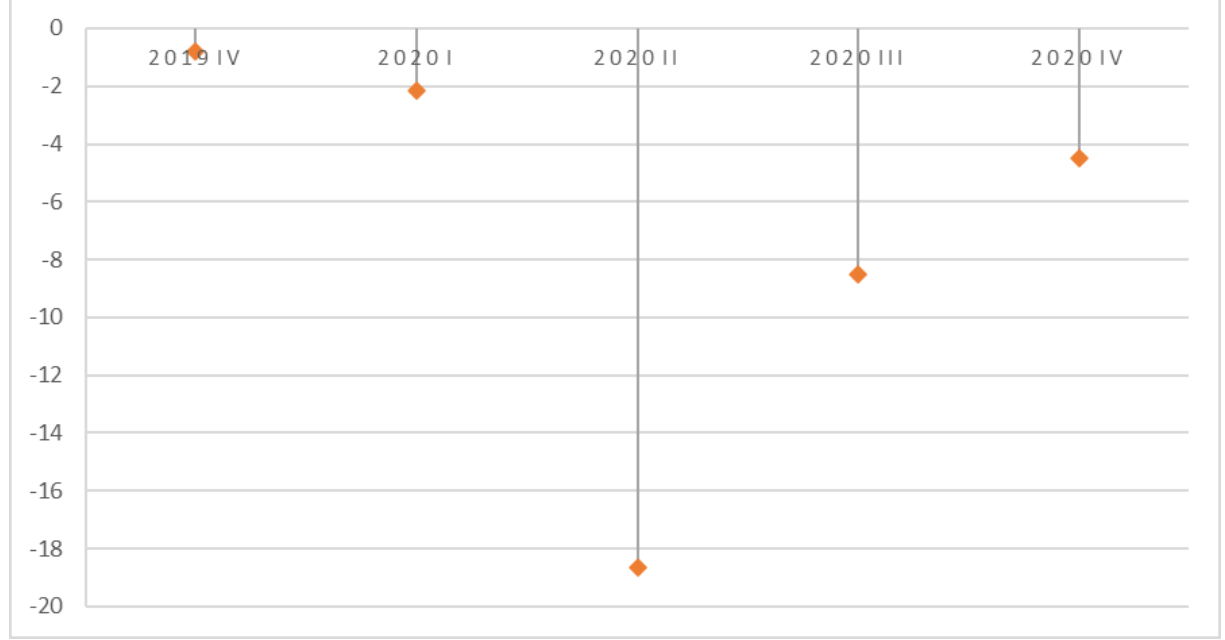

Figure 1. Mexico's GDP growth rates (\%)

Source: National Institute of Statistics and Geography (INEGI), in millions of pesos, using 2013 prices, with seasonal adjustments.

\footnotetext{
${ }^{6}$ Other papers have addressed a variety of other Covid-19 effects in Mexico. Cabrera-Hernández and Padilla-Romo (2020) estimate the effects of Covid-19 related school closures on the reporting of child maltreatment in Mexico City, finding an average reduction of $29 \%$ and 30\%. Llamas (2020) examines the impact of Covid-19 on the country's education system, finding it has accelerated the adoption of new ICT (Information and Communication Technologies). Mendoza-Rivera et al. (2020) investigate whether Covid-19 has impacted several Latin American countries' financial variables, including México, finding that the pandemic death tolls have negatively impacted their stock indexes and interest rates.

${ }^{7}$ At the time of this writing (March 2021), 2021 data is not still available. However, it does not seem likely that the country had recovered.
} 
From a historical perspective, Mexico's recent economic performance has not been impressive, averaging around 1\% GDP per capita growth since the 1980s. In explaining this slow growth, a body of literature has argued the low rate of capital accumulation as its most important proximate cause (Moreno-Brid et al., 2005; Moreno-Brid and Ros, 2009; Ros 2013, 2015; GómezRamírez, 2019). As a result, it seems particularly relevant to examine the pandemic's impact on the country's capital accumulation. Figure 2 presents data on Mexico's quarterly nominal gross capital formation growth rates (\%) from the fourth quarter of 2019 to the third quarter of 2020 (the most recent data available at the time of writing). These rates are in comparison with the same quarter of the previous year. Interestingly, it can be seen that investment contracted before the pandemic. However, in the second quarter of 2020, gross capital formation fell by an astounding $27.9 \%$. Figure 2 also shows that in the third quarter of 2020 , the capital formation was also reduced by $12.8 \%$. This suggests that the pandemic has had a very negative impact on what could be a key variable explaining Mexico's slow growth over the last four decades. This is highly worrisome.

Consumption expenditures, while less procyclical than investment, are also an important measure of economic cycles. Figure 3 presents data on Mexico's quarterly nominal final consumption expenditures growth rates (\%) from the first quarter of 2019 to the third quarter of 2020 (the most recent data available at the time of writing). These rates are in comparison with the same quarter of the previous year. Consumption growth rates had been modestly positive before the pandemic, but in the second quarter of 2020, consumption contracted $14.8 \%$ year-over-year. Furthermore, in the third quarter of 2020 consumption was still 7.1\% lower than in the third quarter of 2019. Again, thus, this suggests Covid-19 has had significant detrimental effects on Mexico's consumption.

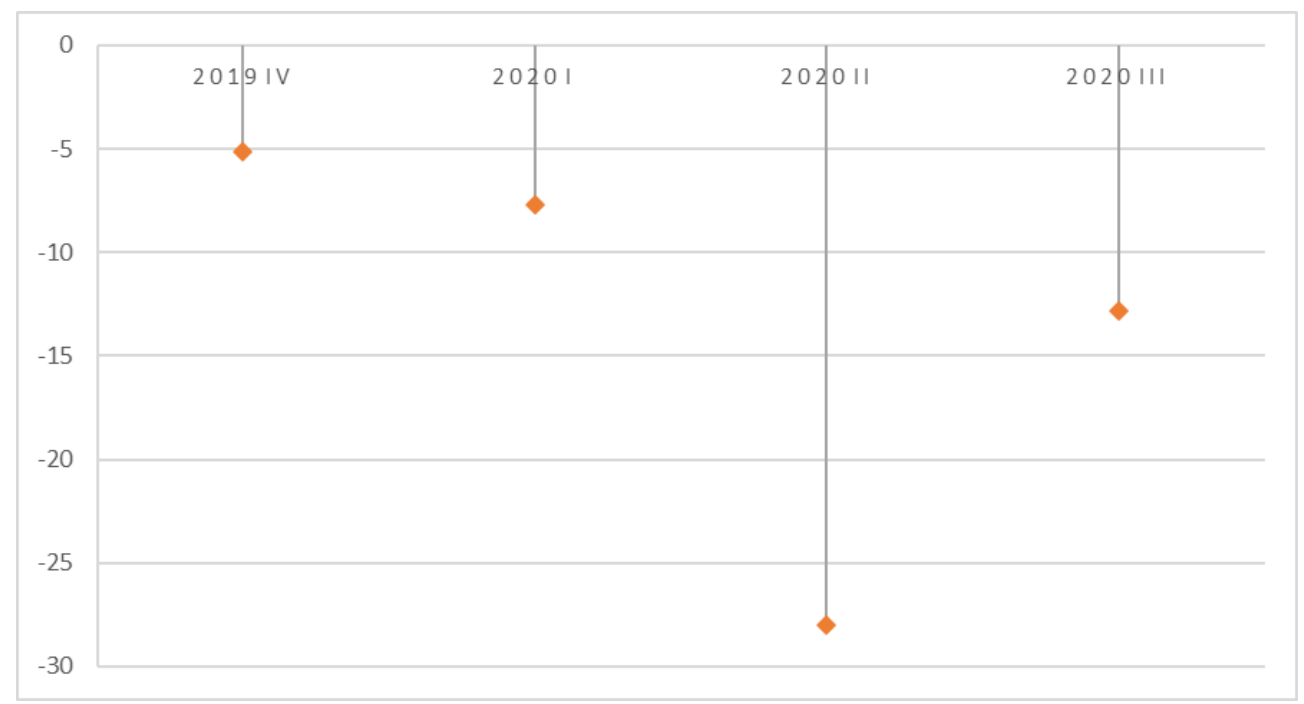

Figure 2. Mexico's gross capital formation growth rates (\%)

Source: National Institute of Statistics and Geography (INEGI) in millions of pesos, current prices. 


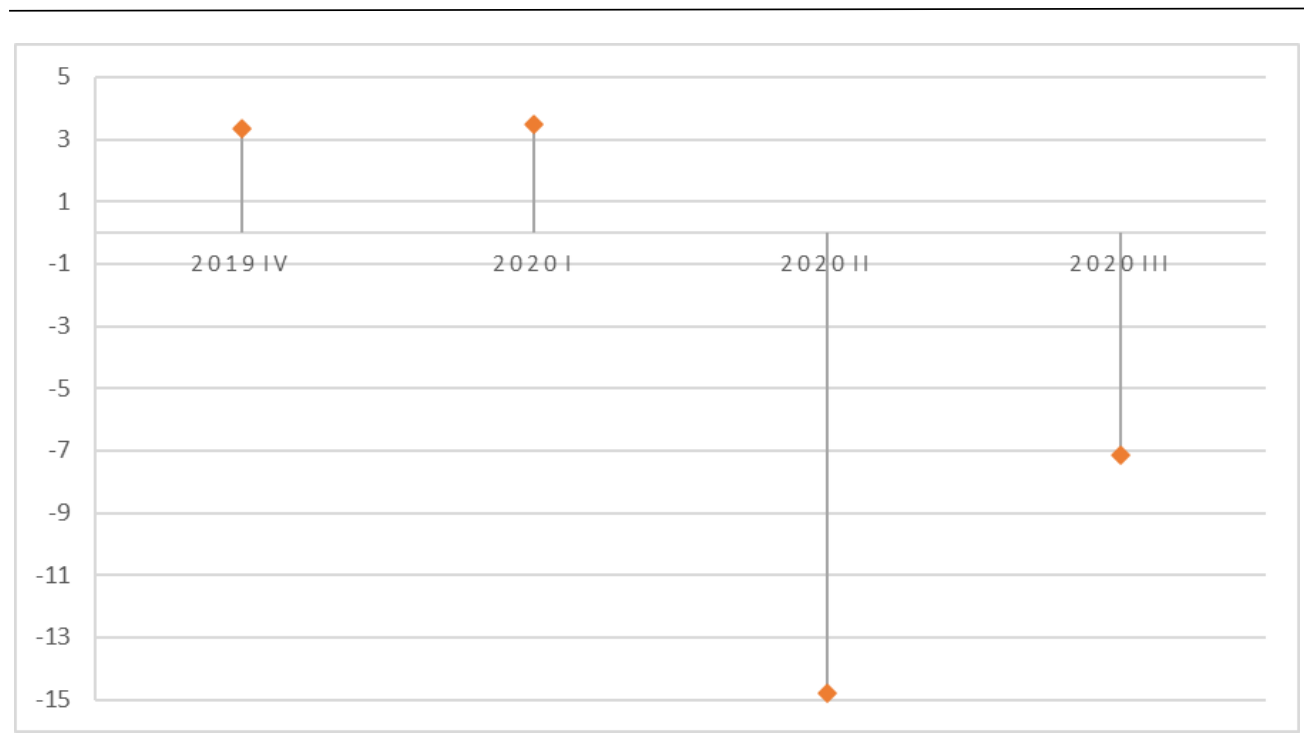

Figure 3. Mexico's consumption expenditures

Source: National Institute of Statistics and Geography (INEGI) in millions of pesos, current prices.

Since its liberalizing processes began in the 1980s, the Mexican economy experienced an impressive surge in exports. This has not, however, delivered high and sustained growth for the economy at large, giving rise to the apparent paradox of Mexico's export boom without growth (Moreno-Brid and Ros, 2009; de Souza and Gómez-Ramírez, 2018). Therefore, it is also important to examine data on the impact of Covid-19 on the country's exports. Figure 4 presents data on quarterly nominal exports. In order to understand that the impact of Covid-19 on this variable has been somewhat different from the output, investment, and consumption ones, it is better to present the data in levels and an extended period, namely, from the first quarter of 2018 to the third quarter of 2020 (the most recent data available at the time of writing). Interestingly, the data shows exports had already experienced a significant slowdown in 2019 (after being volatile but, on average, higher in 2018) before the Covid-19 pandemic. Compared with the last quarter of 2019, in the first quarter of 2020 , exports had already been $16.6 \%$ smaller. In any case, in comparison with the already low first quarter of 2020, in the second quarter of 2020, exports contracted by $10.8 \%$, which suggests the pandemic, in fact, negatively affected exports. However, in the third quarter of 2020, exports experienced a 57\% increase and recovered to roughly 2018 levels. All this suggests that Covid-19 exerted a negative but very short-lived effect on exports. In fact, in the next quarter after the economic shutdown, that is, the third of 2020, they were already almost at their significant levels of the last three years (just below the three years peak obtained in the second quarter of 2018). 


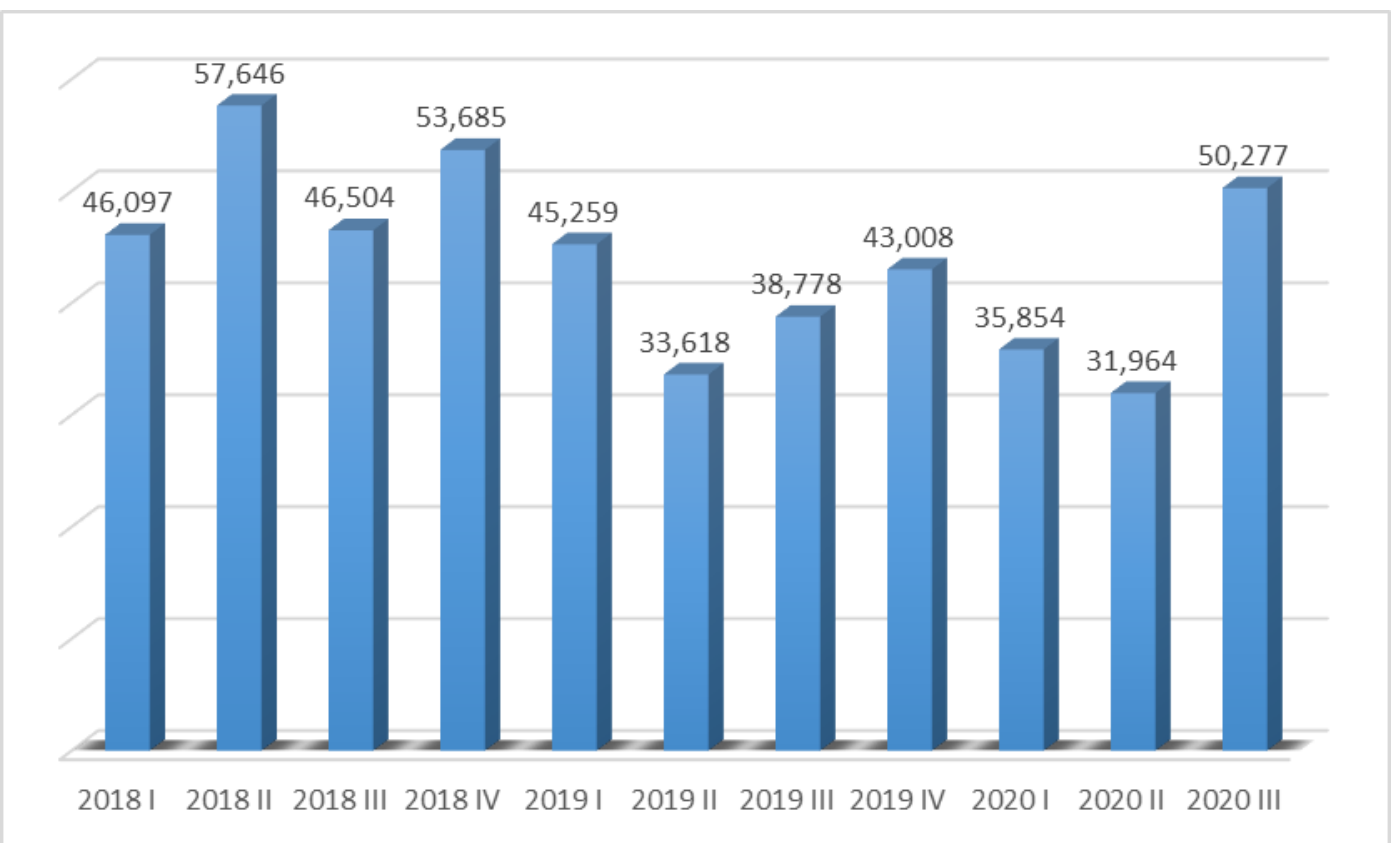

Figure 4. Mexico's exports

Source: National Institute of Statistics and Geography (INEGI) in millions of pesos, current prices.

In light of the substantial detrimental impact of Covid-19 on Mexico's economy, it should not be surprising that there have been ubiquitous calls for expansionary, countercyclical policies, both monetary and fiscal. However, by themselves, those policies might increase Covid-19 contagion. This fundamental dilemma calls for a deeper examination of expansionary policies in the middle of the pandemic.

\section{COVID19 and output, a dynamic model}

We investigate the impact of expansionary policies using a dynamic model. When $z$ denotes active Covid-19 cases and $y$ denotes output, we assume the following general model captures their dynamic interaction:

$$
\begin{gathered}
\dot{z}=a z+b y \\
\dot{y}=-c z+d y
\end{gathered}
$$

We suppose that $a>0$ and $b>0$, which means equation (1) expresses the Covid-19 rate of change is positively related to both its own and output levels. There is ample epidemiological evidence supporting the former assumption. Concerning the latter, if it were not true, then there would not have been any economic shutdown in the first place (and perhaps our lives would not have been so dramatically altered by the pandemic). 
We also suppose that $c>0$ and $d>0$, which means equation (2) expresses output rate of change is inversely related to the Covid-19 level and positively related to its own level. ${ }^{8}$ For the former, it could be simply pointed out that when people get sick or die of Covid-19, they cannot contribute to output and often require others' care. ${ }^{9}$ The latter is a standard assumption in short-run Keynesian economics, and long-run neoclassical economics endorses it too. In what follows, what we formally understand as expansionary policies (countercyclical or Keynesian) are those increasing $d$.

Given initial conditions $y[0]=y_{0}$ and $z[0]=z_{0}$, solutions of the system (1)-(2) are

$$
\begin{gathered}
z[t]=c_{1} e^{\lambda_{1} t}+c_{2} e^{\lambda_{2} t} \\
y[t]=c_{1}\left(\frac{\lambda_{1}-a}{b}\right) e^{\lambda_{1} t}+c_{2}\left(\frac{\lambda_{2}-a}{b}\right) e^{\lambda_{2} t}
\end{gathered}
$$

in $\quad$ which $\quad \lambda_{1}=\left(\frac{1}{2}\right)\left(a+d+\left[(a-d)^{2}-4 b c\right]^{\frac{1}{2}}\right), \quad \lambda_{2}=\left(\frac{1}{2}\right)\left(a+d-\left[(a-d)^{2}-4 b c\right]^{\frac{1}{2}}\right), \quad c_{1}=$ $W^{-\left(\frac{1}{2}\right)}\left[\left(\frac{z_{0}}{2}\right)\left(W^{\frac{1}{2}}+a-d\right)+y_{0} b\right], c_{2}=W^{-\left(\frac{1}{2}\right)}\left[\left(\frac{z_{0}}{2}\right)\left(W^{\frac{1}{2}}+d-a\right)-y_{0} b\right]$, with $W=(a-d)^{2}-4 b c$. The only stationary point of the system is $0=\left(y^{*}=0, z^{*}=0\right)$.

The dynamics along time exhibit two cases depending on whether $W \geq 0$ or $W<0$. On the one hand, if $W<0$, then $\lambda_{1}$ and $\lambda_{2}$ are complex conjugate numbers with a positive real part and, therefore, 0 is a spiral source or unstable focus. In this case, Covid-19 and output diverge from 0 forming ever-increasing ("explosive") counter-clockwise oscillations. In other words, in this scenario Covid-19 and output exhibit ever-larger boom and bust cycles. Figure 5's right panel presents the system phase diagram of this situation.

It could be seen that $W=(a-d)^{2}-4 b c<0$ is the more likely to be the case if, ceteris paribus, $a-d$ is small, $b$ is large, and $c$ is large. This suggests a first important policy implication of the analysis, yielding support to expansionary policies' desirability. This is the case because, by increasing $d$, the economy can avoid this boom-and-bust scenario.

On the other hand, if $W \geq 0$, then $\lambda_{1}>0, \lambda_{2}>0$ and both are real. Thus, 0 is a source or unstable node. In this case, Covid-19 and output dynamics along time will be pinned down by their initial conditions. It could be seen that, unlike the former case, $W=(a-d)^{2}-4 b c \geq 0$ is more likely to occur if, ceteris paribus, $a-d$ is large, $b$ is small, and $c$ is small. The left panel of Figure 5 presents the system phase diagram of this case and illustrates the different dynamics in this scenario. In it, the $\dot{z}=0$ locus is given by the downward sloping line $z=-\left(\frac{b}{a}\right) y$, with Covid-19 rate of change being positive (negative) if the variables are above (below) it. For its part, the $\dot{y}=0$ locus is given by the upward sloping line $z=\left(\frac{d}{c}\right) y$, with the output rate of change being negative (positive) if the variables are above (below) it.10 Taken together, these processes yield four possible dynamic areas: in area $A$, both Covid-19 and output grow; in area $B$, the pandemic grows and output decreases; in area $C$, both decrease; and in area $D$, Covid-19 shrinks and output grows. Assuming that society's welfare is decreasing in the pandemic and increasing in output, we can conclude that (i) area $B$ is the

8 Of course, a more complicated model of Covid-19 and output dynamics could include non-linearities (and higher-order differential equations). For this paper, however, a system of first-order linear differential equations suffices.

${ }^{9}$ In any case, the qualitative results to follow are not fundamentally altered if $c=0$.

10 In Figures 5 and 6, we draw the stationary loci assuming $a=b$ and $c=d$, which is not necessarily the case. 
worst-case, (ii) areas $A$ or $C$ are second best, 11 and (iii) area $D$ is the best-case. Initial conditions determine where society would be.

Note now, however, that we can dismiss several initial conditions in the context of our analysis. First, those in which $z_{0} \leq 0$ are irrelevant. To begin with, there actually was (and still is) a pandemic with significant quantities of active cases. Second, we can ignore cases in which $y_{0} \leq 0$ because the pandemic did not arrive in Mexico when it was already experiencing a severe crisis (which is not to say, of course, it was performing exceptionally well either). Therefore, we can narrow down our analysis to the positive quadrant of the Cartesian plane. ${ }^{12}$

But then it follows that, unfortunately, society can only be in either the worst-case area $B$ or the second-best area $A$. It cannot be in the best-case area $D$. In other words, given the sensible initial conditions $y_{0}>0, z_{0}>0$, the model shows it is impossible to reach the desired situation in which the pandemic shrinks and output grows.

We can also conclude that expansionary policies are, nevertheless, desired. This is the case because, by increasing $d$, they make the $\dot{y}=0$ locus steeper, enlarging area $A$ in the positive quadrant and reducing $B$ 's area, helping us avoid it. In other words, countercyclical policies could help to put the economy in the situation in which even though Covid-19's rate of change is positive, at least the output rate of change is positive too, which is better than being in the situation in which the former is positive and the second is negative.

The significant caveat to this result is, however, that expansionary policies cannot achieve better. They cannot avoid increasing contagion but only could help it not go hand in hand with a depressed economy. This is an important caveat, we believe, which should not be neglected in the policy-making analysis raised by the pandemic.
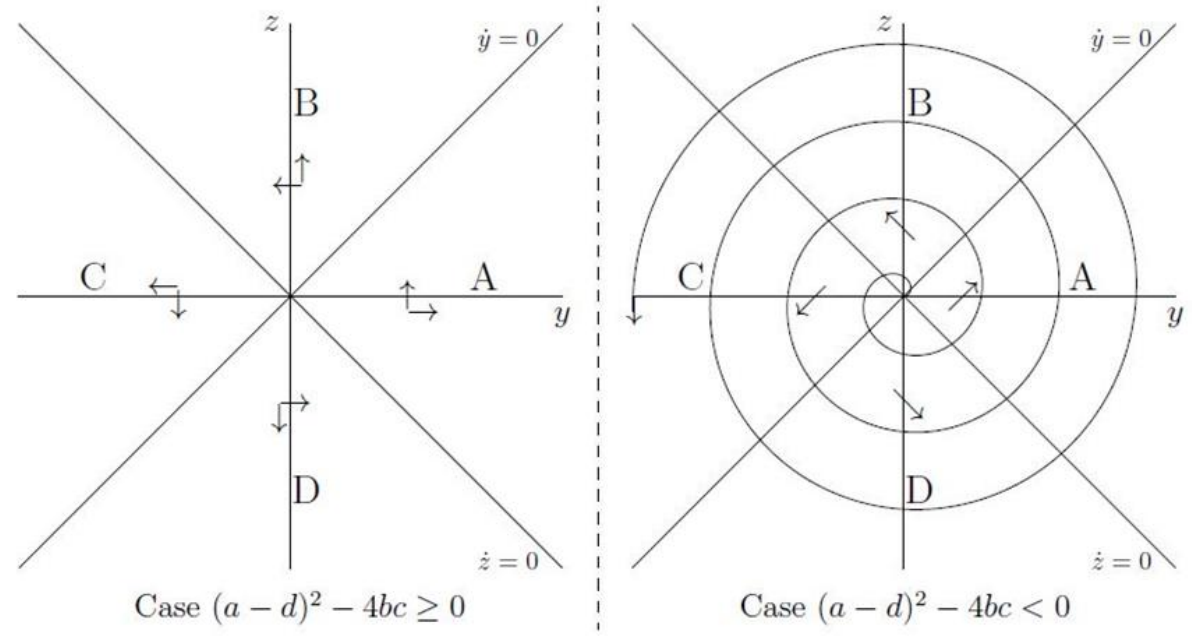

Figure 5. COVID19 and output coevolving dynamics

\footnotetext{
11 Unless we also make further assumptions about the weights of health and income in society's welfare, we cannot say which, A or C, is better. For this paper's purposes, however, it is not necessary to go into these thorny issues.

12 To be clear, if $z$ and $y$ are literally interpreted as Covid-19 and output quantities, then $z_{0} \leq 0$ or $y_{0} \leq 0$ would not even make sense. They could, therefore, be interpreted as some positive initial levels (indexes) of Covid-19 cases and production, respectively.

If we would like to interpret the fact that Mexican output was perhaps experiencing a recession before the pandemic (of $2.1 \%$ in $2020 q 1$, in comparison with 2019q1), we would have to include area $C$ in the analysis. Nevertheless, it would only complicate the analysis without changing the key findings of our examination.
} 
The question is, therefore, if we are necessarily trapped in this second-best scenario or is there something else that could be done. As we will see next, combining supplementary policies (especially public health policies) together with Keynesian policies can actually help Mexico reach the best-case scenario.

\section{Expansionary and supplementary policies}

Suppose the following extended model of Covid19 active positive cases and output dynamic interactions:

$$
\begin{gathered}
\dot{z}=a z+b y-e \\
\dot{y}=-c z+d y+f
\end{gathered}
$$

As before, we keep assuming $a, b, c, d>0$. We now, however, further assume $e>0$, which means equation (5) allows now for factors to negatively affect the pandemic rate of change independently of its own and output levels effects (independently of the parameters $a$ and $b$ ). Furthermore, we now suppose $f>0$, which means equation (6) allows for factors to positively affect output rate of change independently of Covid-19 and its own levels effects (independently of the parameters $c$ and $d$ ). In what follows, what we formally understand by supplementary policies are those which affect $e$ and $f$. In the case of $e$, leading examples are public health policies like vaccination or regulating citizens' behaviors in ways that reduce the contagion (like wearing masks and keeping social distance). The parameter $f$ might represent a one-time increase in public investment, for example.

Given initial conditions $y[0]=y_{0}$ and $z[0]=z_{0}$, solutions of the system (5)-(6) are

$$
\begin{gathered}
z[t]=z^{S}+c_{1} e^{\lambda_{1} t}+c_{2} e^{\lambda_{2} t} \\
y[t]=y^{S}+c_{1}\left(\frac{\lambda_{1}-a}{b}\right) e^{\lambda_{1} t}+c_{2}\left(\frac{\lambda_{2}-a}{b}\right) e^{\lambda_{2} t}
\end{gathered}
$$

in which $\lambda_{1}, \lambda_{2}, c_{1}$, and $c_{2}$ are the same as before (equations 3 and 4) while $z^{s}=\frac{b f+d e}{a d+b c}$ and $y^{s}=$ $\frac{c e-a f}{a d+b c}$. The only stationary point of the system is given by $S=\left(z^{S}, y^{S}\right)$ where $z^{S}>0$ and, under the assumption that $c e>a f, y^{s}>0$; which we indeed assume because we want to narrow the analysis to the situation in which $S$ happens to be in the positive quadrant of the Cartesian plane. ${ }^{13}$

Again, this dynamical system exhibits two cases depending on whether $W=(a-d)^{2}-$ $4 b c \geq 0$ or $W<0$. In the second case $S$ is a spiral source or unstable focus, so that pandemic and output diverge from it in increasing counterclockwise oscillations. Like before, by increasing $d$, expansionary policies might help avoid this ever-larger boom and bust cycles dynamics. In what follows, we focus on the case in which $W \geq 0$, so that $S$ is a source or unstable node.

\footnotetext{
13 The key result that expansionary policies together with public health policies can put the economy in the best-case scenario is not altered if we assume $c e<a f$ (and thus $y^{s}<0$ ).
} 
And in this case, an important result which follows is that, for given initial conditions $y_{0}>0$ and $z_{0}>0$, society could still be in the best-case scenario in which Covid-19 shrinks and output grows. Figure 6 helps to understand this result. The inclusion of supplementary policies in Covid-19 and output dynamics shifts both the locus $\dot{z}=0$ and the locus $\dot{y}=0$ upwards. The first is now given by the line $z=-\left(\frac{b}{a}\right) y+\left(\frac{e}{a}\right)$, which we label $\dot{z}=0^{\text {sup }}$. The second is now given by $z=-\left(\frac{d}{c}\right) y+\left(\frac{f}{c}\right)$, which we label $\dot{y}=0^{\text {sup }}$. There is now a range of initial conditions $y_{0}>0$ and $z_{0}>0$ such that Covid19 rate of change is negative and the output rate of change is positive. Specifically, this set of positive initial conditions lies in the irregular quadrilateral given by $(y=0, z=0)-\left(y=0, z=\frac{f}{c}\right)-$ $\left(y^{s}, z^{s}\right)-\left(y=\frac{e}{b}, z=0\right)$.

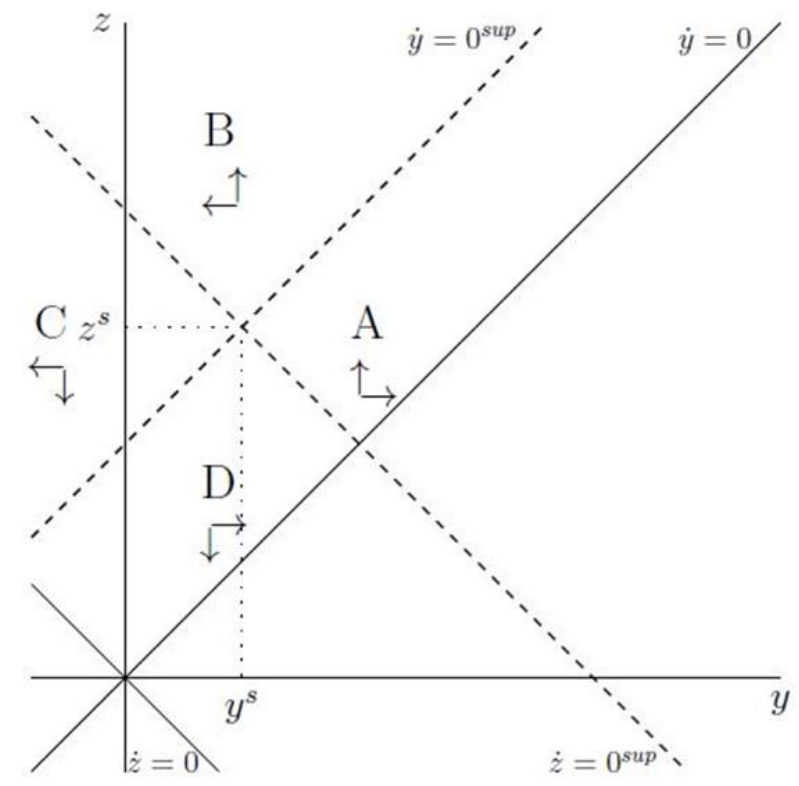

Figure 6. The role of supplementary policies

It also follows that, given the supplementary presence of health policies, more aggressive Keynesian policies could actually help put the economy in the best path in which the pandemic shrinks and the economy grows. In other words, supplementary policies together with expansionary allow society to reach this best-case scenario. In Figure 7 we highlight in detail this key result. It shows that, by increasing $d$, expansionary policies make the $\dot{y}=0^{\text {sup }}$ null-cline rotate counterclockwise over its fixed $\frac{f}{c} z$-axis intercept fixed, thereby enlarging area $D$ in the positive quadrant. For comparison with the previous model, Figure 7 labels the null-cline with them $\dot{y}=0^{\exp }$ and shows it is steeper. The Figure also shows the stationary point is now given by $S^{\exp =}$ $\left(z^{s, \exp }, y^{s, \exp }\right)$, which is such that $z^{s, \exp }>z^{s}$ and $y^{s}<y^{s, \exp }$. Most importantly, it shows that the larger $d$ is the greater the area of the irregular quadrilateral given by $(y=0, z=0)-$ $\left(y=0, z=\frac{f}{c}\right)-\left(y^{s, \exp }, z^{s, e x p}\right)-\left(y=\frac{e}{b}, z=0\right)$, that is, the area of positive initial conditions in which the pandemic will shrink and the economy will thrive.

It is worth spelling out in detail the myriad of other policies, in addition to Keynesian policies, which would help society arrive at the best-case scenario. There are five. Policies (i) reducing the 
positive effect of Covid-19 level on its rate of change (lowering a); (ii) reducing the positive effect of output level on the pandemic (lowering b); (iii) decreasing Covid-19 rate of change through health policies (increasing $e$ ); (iv) reducing the negative effect of the pandemic level on output rate of change (lowering $c$ ); and (v) increasing output rate of change through other than Covid-19 and its own levels effects (increasing $f$ ).

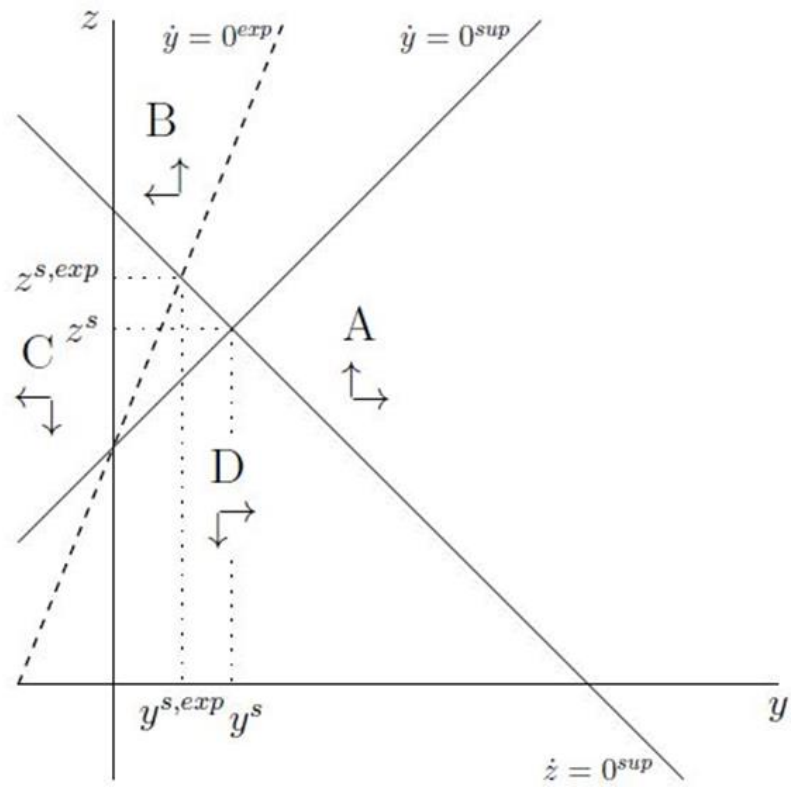

Figure 7. Supplementary and aggressive expansionary policies

Finally, related to the interaction between expansionary policies and the implementation of public health policies, there's a subtle but intuitive possibility which is worth examining further, if only briefly. It is that, if output is boosted through expansionary policies, then a side-effect of them could be to increase government's revenues, but it in turn could boost the implementation of larger public health policies, thus further helping to put the society in the desired situation in which Covid19 shrinks and output grows. ${ }^{14}$ Within the context of this paper's bidimensional dynamic system, a parsimonious way to examine this intuitive possibility is by modeling the level of $e$ as positively related to output as well. Consider, for example, the following linear specification

$$
e=g y+h
$$

in which $g, h>0$. In this case, equation (5) would become:

$$
\dot{z}=a z+(b-g) y+h
$$

Therefore, the $\dot{z}=0$ null-cline would be given by the line $z=-\left(\frac{b-g}{a}\right) y+\left(\frac{h}{a}\right)$, which let us label $\dot{z}=0^{\text {exphealth }}$. It is the case that $\dot{z}=0^{\text {exphealth }}$ is more horizontal than $\dot{z}=0^{\text {sup }}$, which very likely enlarges the desired area $D$ in the positive quadrant. In fact, if we also assume $h$ is not smaller than $e$

14 We thank an anonymous referee for pointing this out to us. 
of equation (5) -a sensitive assumption to make if the government is strongly interested in reducing the contagion through public health policies - then we can be totally sure area $D$ is enlarged in the positive quadrant. It is then obtained that, if expansionary policies increase government's capabilities to implement public health policies (because the former help raising fiscal revenues), the likelihood of getting out of the pandemic and simultaneously increasing output is increased.

\section{Concluding comments}

Covid-19 impact on Mexico's economy has been severe. It is not surprising, therefore, that calls for expansionary, "Keynesian" policies -monetary and fiscal- intending to counteract the acute economic crisis have been ubiquitously voiced in the media and in a burgeoning scholarly literature (Casar, 2020; Cárdenas, 2020; Panico, 2020; Moreno-Brid 2020). Unfortunately, Covid-19 does not constitute a standard economic crisis that can be simply addressed through expansionary monetary or fiscal policy. In the absence of further policies, a growing economy could also boost the pandemic's contagion rate. The dynamic model presented in this paper analyzes this fundamental dilemma.

We examined, first, a dynamic model of Covid-19 and output and found that expansionary policies are a partial blessing. On the one hand, (i) they can help avoid boom-and-bust cycles, and (ii) can also help avoid the worst-case scenario in which output shrinks and the pandemic grows. On the other hand, they are impotent in escaping the pandemic. This is a significant caveat that should not be overlooked in policy-making in response to the pandemic analysis.

Second, we investigated a model in which supplementary policies, especially public health policies, are included, such as vaccination, mask mandates, and social distancing rules. In the presence of these other policies, Keynesian policies help put the economy in the best-case scenario in which the pandemic shrinks and the economy thrives.

Among the several topics arising for future research from this paper, inquiring about empirical evidence supporting our theoretical findings would be -clearly- an important one.

This paper's bottom line is straightforward: expansionary countercyclical policies are clearly desirable if there are also other supplementary policies, like public health regulations, that address the pandemic. This is an important conclusion we believe scholars and policymakers must keep in mind. We believe this is particularly relevant in the current Covid-19 crisis. However, given that human-caused climate change seems unstoppable, it seems likely new pandemics will emerge, and policy will, again, have to protect health while also maintaining economic output. ${ }^{15}$

\footnotetext{
15 The World Health Organization (WHO) has stated that "There is no evidence of a direct connection between climate change and the emergence or transmission of COVID-19 disease". However. it adds that "More generally, most emerging infectious diseases, and almost all recent pandemics, originate in wildlife, and there is evidence that increasing human pressure on the natural environment may drive disease emergence" (https://www.who.int/news-room/q-adetail/coronavirus-disease-covid-19-climate-change).
} 


\section{References}

[1] Cabrera-Hernández, F. and Padilla-Romo, M. (2020). Hidden Violence: How COVID-19 School Closures Reduced the Reporting of Child Maltreatment. Latin American Economic Review, 29(4): 1-17. https://doi.org/10.47872/laer-2020-29-4s

[2] Casar, J. (2020). Razones de la política económica, resultados y necesidad de un cambio de rumbo. EconomíaUNAM, 17(51): 227-240. https://doi.org/10.22201/fe.24488143e.2020.51.560

[3] Cárdenas, E. (2020). México en la pandemia: atrapado en la disyuntiva salud vs economía. EconomíaUNAM, 17(51): 282-295. https://doi.org/10.22201/fe.24488143e.2020.51.564

[4] Cordera, R. (2020). Natura contra economía: apuntes preliminares sobre el "gran desencuentro". EconomíaUNAM, 17(51): 7-15. https://doi.org/10.22201/fe.24488143e.2020.51.539

[5] Dávila-Flores, A. and Valdés-Ibarra, M. (2020). México. Costos económicos del cierre de las actividades "no esenciales" por la pandemia Covid-19. Análisis multisectorial y regional con modelos SAM. Economía Teoría y Práctica, número especial (2020): 15-43. http://dx.doi.org/10.24275/ETYPUAM/NE/E052020/Davila

[6] de Souza, J.P. and Gómez-Ramírez, L. (2018). The Paradox of Mexico's Export Boom Without Growth: A Demand-Side Explanation, Structural Change and Economic Dynamics, 47: 96-113. https://doi.org/10.1016/j.strueco.2018.08.001

[7] Esquivel, G. (2020). Los impactos económicos de la pandemia en México. EconomíaUNAM, 17(51): 2844. https://doi.org/10.22201/fe.24488143e.2020.51

[8] Gómez-Ramírez, L. (2019). Credit Constraints and Investment in Mexico, an Empirical Test. Revista Mexicana de Economía y Finanzas, 14(3): 415-432. https://doi.org/10.21919/remef.v14i3.311

[9] Llamas, I. (2020). Covid-19 como acelerador del tránsito hacia un nuevo modelo educativo: análisis, retos y obstáculos. Economía Teoría y Práctica, número especial (2020): 99-123. http://dx.doi.org/10.24275/ETYPUAM/NE/E052020/Llamas

[10] Mendoza-Rivera, R. J., Lozano-Díez, J. A., and Venegas-Martínez, F. (2020). Impacto de la pandemia Covid-19 en variables financieras relevantes en las principales economías de Latinoamérica. Economía $\begin{array}{lllll}\text { Teoría } y \text { Práctica, } & \text { número } & \text { 12020): }\end{array}$ http://dx.doi.org/10.24275/ETYPUAM/NE/E052020/Mendoza

[11] Moreno-Brid, J.C. (2020). Pandemia, política pública y panorama de la pandemia mexicana en 2020. EconomíaUNAM, 17(51): 335-348. https://doi.org/10.22201/fe.24488143e.2020.51.569

[12] Moreno-Brid, J. C., and Ros, J. (2009). Development and growth in the Mexican economy: a historical perspective. Oxford University Press.

[13] Moreno-Brid, J. C., Rivas, J. C., and Santamaría, J. (2005). Industrialization and Economic Growth in Mexico After NAFTA: The Road Travelled. Development and Change, 36(6), 1095-1119. https://doi.org/10.1111/j.0012-155X.2005.00451.x

[14] Panico, C. (2020). La coordinación de las políticas económicas en los tiempos del Coronavirus. EconomíaUNAM, 17(51): 214-226. https://doi.org/10.22201/fe.24488143e.2020.51.559

[15] Ros Bosch, J. (2013). Algunas tesis equivocadas sobre el estancamiento económico de México. El Colegio de México - Universidad Nacional Autónoma de México.

[16] Ros Bosch, J. (2015). ¿Cómo salir de la trampa del lento crecimiento y alta desigualdad? El Colegio de México - Universidad Nacional Autónoma de México.

[17] Salas, C., Quintana, L., Mendoza, M.A., and Valdivia, M. (2020). Distribución del ingreso laboral y la pobreza en México durante la pandemia de la Covid-19. Escenarios e impactos potenciales. El Trimestre Económico, 87(348): 929-962. https://doi.org/10.20430/ete.v87i348.1148

[18] Samaniego, N. (2020). El Covid-19 y el desplome del empleo en México. EconomíaUNAM, 17(51): 306314. https://doi.org/10.22201/fe.24488143e.2020.51.566 
[19] Suárez-Davila, F. (2020). Un sistema financiero para el desarrollo después del coronavirus. EconomíaUNAM, 17(51): 248-262. https://doi.org/10.22201/fe.24488143e.2020.51.562

[20] Sundaram, J.K. (2020). Contener el contagio de Covid-19: lecciones comparativas. El Trimestre Económico, 87(348): 1059-1079. https://doi.org/10.20430/ete.v87i348.1175

[21] Toporowski, J. and Levy-Orlik, N. (2021). Cómo pagar por la crisis del coronavirus: una propuesta para la Secretaria de Hacienda. EconomíaUNAM, 18(52): 186-204. https://doi.org/10.22201/fe.24488143e.2021.52.605

[22] Zuñiga,N. G. (2021). Impacto del SARS-CoV-2 sobre el empleo y presupuesto de salud en México. EconomíaUNAM, 18(52): 205-215. https://doi.org/10.22201/fe.24488143e.2021.52.606 